\title{
Application of Exponential Comparison Method and Simple Additive Weighting Method in Assessment of Agricultural Extension Performance
}

\author{
Dewi Suranti \\ Informatics Engineering, Department, Dehasen Bengkulu University, Indonesia \\ Email: dewisuranti@unived.ac.id
}

\begin{abstract}
In order to build qualified and reliable agricultural human resources, it is necessary for professional, creative, innovative and global oriented Agricultural Extension workers in the provision of productive, effective and efficient extension services. Agricultural Extension is directed to carry out advisory and consultation tasks for the main actors and business actors in developing their agribusiness business, so the adoption of appropriate technology can run well and in turn increase the empowerment of the main actors, productions, productivity, income and welfare of farmers and their families. The performance of agricultural extension workers can be seen in the aspects of preparation, implementation, evaluation and reporting, development of agricultural extension and agricultural extension profession. In addition, agricultural extension programs should be based on analysis of farmers' needs and reflect current target audience conditions. The implementation of Simple Additive Wighted (SAW) and Exponential Comparison Method aims to know the performance of agricultural extension in conducting counseling at UPT BPP Sukaraja. This is due to the lack of extension workers in BP3K Sukaraja. The results of the resulting assessment in the form of work performance ranking of each extension worker. Based on the results of the calculation both methods show the same performance rankings. With this is expected to make it easy for UPT BPP sukaraja in carrying out routine performance appraisal performance of extension workers who had been a constraint in conducting appraisal performance extension. Agricultural extension workers can carry out their duties and responsibilities
\end{abstract}

Keywords: Appraisal of Agricultural Extensionist, Simple Additive Wighted, Exponential Comparison Method

\section{INTRODUCTION}

A good agricultural extension performance is the dream of every agricultural stakeholder. The performance of agricultural extension workers can be seen in aspects of preparation, implementation, evaluation and reporting, development of agricultural extension and agricultural extension professional development. In addition, leadership aspects, communication, business partnerships and technology dissemination as well as mastery of the technical field of expertise also greatly determine the success rate of a counselor. The performance of agricultural extension agents on the aspects of preparation, implementation, evaluation and reporting is a systematic and structured sequence in an integral 
path. Agricultural extension programs should be based on an analysis of the needs of farmers and reflect current target audience conditions and target audience conditions that will be realized [1].

UPT BPP Sukaraja strives to improve the performance of extension workers because it is feared will have a negative impact on agricultural development. According to the Head of UPT of Food Security Agency of Kecamatan Sukaraja, Seluma Regency is still classified as a shortage of agricultural extension workers at this time. Therefore we need a research to find out how far the performance of agricultural extension in Seluma regency especially at UPT BPP Sukaraja at this time. By knowing the performance of agricultural extension is expected to be arranged a more directed form of guidance to agricultural extension so that agricultural extension activities in the future can be implemented more effectively and effectively.

One of the methods used in agricultural extension performance appraisal is using the Simple Additive Weighting method [2] and the Exponential Comparison Method (MPE) [3]. With both methods it is expected to be applicable in the appraisal performance of agricultural extension workers for the alternatives.

SAW method is a method by determining the weight value for each attribute, then followed by a ranking process that will select the best alternative from a number of alternatives. Another reason is the use of the Simple Additive Weighting method because the inputted data does not have to be data crips, in contrast to the classic Multi Attribute Decision Making (MADM) method in which the input of the assessment data must be data crips [4]. With this method based on the weight that has been formed so as to get more accurate results on performance appraisal.

The exponential comparison is a scoring method of choice, different values between criteria can be differentiated depending on the ability of the assessing person capable of determining the alternative priority order of decision by using several criteria. For the resulting score scores will illustrate the order of priority that becomes large, this resulted in an alternative priority order of decision becoming more apparent [3].

The purpose of this research is to evaluate the performance of agricultural extension workers in UPT BPP Sukaraja by using Simple Additive Weighting method and Exponential Comparison Method. With the results of the implementation of these two methods is expected to help UPT BPP Sukaraja in conducting appraisal performance of the extension better and faster, so it can help UPT BPP Sukaraja improve the performance of agricultural extension.

\section{METHODS}

\subsection{Simple Additive Weighting}

According to [5] The SAW method is often also known as the weighted summing method. The basic concept of the SAW method is to find the weighted sum of 
performance ratings on each alternative on all attributes. The SAW method requires the process of normalizing the decision matrix $(\mathrm{X})$ to a scale comparable to all existing alternative ratings. The formula for normalization is as follows:

$r_{i j}= \begin{cases}\frac{X_{i j}}{\max _{i} X_{i j}} & \text { If } j \text { is benefit attribute } \\ \frac{\min _{i} X_{i j}}{X_{i j}} & \text { If } j \text { is cost attribute }\end{cases}$

Where:

Rij: Normalized performance rating value

$\mathrm{Xij}$ : The attribute value that belongs to each Criterion

Max Xij: The greatest value of every Criteria

Min Xij: The smallest value of every Criteria

Benefit: if the greatest value is best

Cost: if the smallest value is best

Where rij is the normalized performance rating of the alternative Ai on the attribute $\mathrm{Cj} ; \mathrm{i}=1,2, \ldots, \mathrm{m}$ and $\mathrm{j}=1,2, \ldots, \mathrm{n}$. The preference value for each alternative ( $\mathrm{Vi}$ ) is given as:

$v_{i} \sum_{j=1}^{n} w_{j} r_{i j}$

Information:

$\mathrm{Vi}$ : The ranking for each alternative

$\mathrm{Wj}$ : The weighted value of each criteria

Rij: Normalized performance rating value

A larger value of Vi indicates that Ai's alternatives are preferred [6]

Steps in determining SAW method:

1. Determining the Criteria that will be used as a reference in decision-making, such as $\mathrm{C} 1$.

2. Determine the corresponding rating of each alternative on each Criterion.

3. Determine the decision matrix based on Criteria $(\mathrm{C} 1)$, then normalize the matrix based on the equation that is adjusted to the type of attribute (attribute gain or cost attribute) so that the matrix normalized R.

4. The final result obtained from the ranking process is the sum of the matrix multiplication normalized $\mathrm{R}$ with the vector preference weight to obtain the largest value selected as the best alternative for example (A1).

\subsection{Exponential Comparison (MPE)}

A larger Vi value according to [7] MPE is able to reduce possible biases in the analysis. For the resulting score will illustrate the order of priority that becomes large, this resulted in an alternative order of priority decision becomes more real 
and is a scoring method against the options available. With this the value of intercriteria can be differentiated depending on the ability of people who judge.

Steps in determining MPE method:

1. Develop alternative decision alternatives.

2. Determine which criteria or comparison of decisions are important to evaluate

3. Determine the importance of each decision criterion

4. Assess all alternatives on each criterion

5. Calculate the score or total value of each alternative

6. Determining the order of priority decisions based on the score or the total value of each alternative.

7. The calculation formulation of values for each alternative is as follows:

Value amount $\left(\mathrm{TN}_{\mathrm{i}}\right)=\sum_{\mu=1}^{m}{ }_{(R K i))^{\mathrm{TKK}} \mathrm{j}}$

Where:

$\mathrm{TNi}=$ Total alternative value $\mathrm{ke}-\mathrm{i}$

$\mathrm{RKij}=$ The relative importance of the $\mathrm{j}$ th criterion on choice of decision $\mathrm{i}$

$\mathrm{TKKj}=$ the degree of importance of the $\mathrm{j}$ decision criterion; $\mathrm{TKKj}>0$; round

$\mathrm{M}=$ number of decision criteria

$\mathrm{N}=$ number of decision choices

$\mathrm{j}=1,2,3, \ldots \mathrm{m}=$ number of criteria

$\mathrm{i}=1,2,3, \ldots \mathrm{n}=$ number of alternatives

\subsection{Performance}

Performance is an achievement achieved by employees in performing a job within an organization. In order to provide employee and organizational feedback, it is necessary to assess the achievement. Whereas, the definition about job performance (job performance) is a successful role achievement obtained by someone from his actions. Achievement means achievement of the work. High performance employees will be productive in their work. It shows that performance is closely related to productivity.

\subsection{Agricultural Extension}

Agricultural counselors are guides who guide their clients to find the science and technology they need to solve their own problems, in this guiding process the farmer is no longer a pupil but as a learning partner who does the learning process. Counselors in this case extension workers, are expected to be tasked with assisting community groups in organizing business and organizing groups. 


\section{RESULTS AND DISCUSSION}

Applying Fuzzy Simple Additive Weighted and Exponential Comparison (MPE) in appraisal of farmer extension performance in BP3K Sukaraja, there are 16 (sixteen) criteria proposed in decision making according to [8] as shown in Table 1:

Table 1.Performance criteria for agricultural extensionist

\begin{tabular}{|c|c|}
\hline Criteria Code & Criteria \\
\hline $\mathrm{C}_{\mathrm{I}}$ & Creating potential regional data and agro ecosystems \\
\hline $\mathrm{C}_{2}$ & Guiding (supervision and companionship) of RDKK drafting \\
\hline $\mathrm{C}_{3}$ & $\begin{array}{l}\text { Preparation of agricultural extensionist program village and sub- } \\
\text { district }\end{array}$ \\
\hline $\mathrm{C}_{4}$ & Create an annual agricultural extensionistworkplan \\
\hline $\mathrm{C}_{5}$ & Implement dissemination / dissemination of extension materials \\
\hline $\mathrm{C}_{6}$ & $\begin{array}{l}\text { Implement the application of agricultural extension methods in } \\
\text { the form of visits }\end{array}$ \\
\hline $\mathrm{C}_{7}$ & $\begin{array}{l}\text { Implemented the application of extension methods in the form of } \\
\text { demonstrations }\end{array}$ \\
\hline $\mathrm{C}_{8}$ & $\begin{array}{l}\text { Implement the application of extension methods in the form of } \\
\text { intersect }\end{array}$ \\
\hline $\mathrm{C}_{9}$ & $\begin{array}{l}\text { Implement the application of extension methods in the form of } \\
\text { courses }\end{array}$ \\
\hline $\mathrm{C}_{10}$ & Implement capacity building of farmers on access to information \\
\hline $\mathrm{C}_{\mathrm{I} 1}$ & $\begin{array}{l}\text { Growing farmer groups / gapoktan from aspects of quality and } \\
\text { quantity }\end{array}$ \\
\hline $\mathrm{C}_{12}$ & $\begin{array}{l}\text { Improving farmer group class from quantity aspect and quality } \\
\text { aspect }\end{array}$ \\
\hline $\mathrm{C}_{13}$ & $\begin{array}{l}\text { Growing and developing the farmer's economic institutions from } \\
\text { the aspect of the number }\end{array}$ \\
\hline $\mathrm{C}_{14}$ & $\begin{array}{l}\text { Increased production of superior commodities in WKPP } \\
\text { compared to previous production }\end{array}$ \\
\hline $\mathrm{C}_{15}$ & Evaluating the implementation of agricultural extension \\
\hline $\mathrm{C}_{16}$ & Making agricultural extension implementation report \\
\hline
\end{tabular}

From these criteria, then made a level of importance criteria based on the weight that has been determined into the fuzzy number. The rating of each alternative matches as in Table 2 as follows:

Table 2. Weight criteria

\begin{tabular}{cc}
\hline Weight & Weight Value \\
\hline 5 & Very High \\
4 & High \\
3 & Medium \\
2 & Low \\
1 & Very Low \\
\hline
\end{tabular}




\subsection{Application of Simple Additive Weighting Method (SAW)}

The implementation of Fuzzy Simple Additive Weighted for agricultural extension performance appraisal is taken for example 5 agricultural extension data by having criteria value as shown in Table 3.

Table 3. The alternate value of each criteria

\begin{tabular}{lcccccccccc}
\hline \multirow{2}{*}{ Alternative } & \multicolumn{10}{c}{ Criteria } \\
\cline { 2 - 11 } & $\mathrm{C}_{1}$ & $\mathrm{C}_{2}$ & $\mathrm{C}_{3}$ & $\mathrm{C}_{4}$ & $\mathrm{C}_{5}$ & $\mathrm{C}_{6}$ & $\mathrm{C}_{7}$ & $\mathrm{C}_{8}$ & $\mathrm{C}_{9}$ & $\mathrm{C}_{10}$ \\
\hline Sirajudin & 5 & 4 & 3 & 4 & 2 & 3 & 5 & 5 & 3 & 5 \\
Nasir Lubis & 5 & 3 & 3 & 3 & 2 & 3 & 5 & 5 & 3 & 3 \\
Sudirman & 5 & 5 & 4 & 3 & 4 & 3 & 5 & 5 & 5 & 3 \\
Sugianto & 3 & 4 & 4 & 4 & 3 & 4 & 3 & 5 & 5 & 4 \\
Eko Susanto & 3 & 2 & 4 & 2 & 3 & 2 & 5 & 5 & 3 & 2 \\
\hline
\end{tabular}

Table 4. The alternate value of each criteria

\begin{tabular}{lcccccc}
\hline \multirow{2}{*}{ Alternative } & \multicolumn{6}{c}{ Criteria } \\
\cline { 2 - 7 } & $\mathrm{C}_{11}$ & $\mathrm{C}_{12}$ & $\mathrm{C}_{13}$ & $\mathrm{C}_{14}$ & $\mathrm{C}_{15}$ & $\mathrm{C}_{16}$ \\
\hline Sirajudin & 3 & 2 & 4 & 3 & 4 & 4 \\
Nasir Lubis & 4 & 3 & 2 & 3 & 3 & 3 \\
Sudirman & 4 & 3 & 4 & 3 & 3 & 4 \\
Sugianto & 4 & 4 & 2 & 2 & 3 & 3 \\
Eko Susanto & 3 & 2 & 3 & 2 & 3 & 3 \\
\hline
\end{tabular}

Here $\mathrm{C}=$ Criteria and Alternative $=$ Agricultural Extensionist, the decision maker gives weight to each criterion, based on the importance level of each required criterion as follows:

Vector Weights $W=\{5,5,5,5,5,5,5,5,5,5,5,5,5,5,5,5\}$

Decision matrix formed from match table as follows:

$$
X=\left\{\begin{array}{llllllllllllllll}
5 & 4 & 3 & 4 & 2 & 3 & 5 & 5 & 3 & 5 & 3 & 2 & 4 & 3 & 4 & 4 \\
5 & 3 & 3 & 3 & 2 & 3 & 5 & 5 & 3 & 3 & 4 & 3 & 2 & 3 & 3 & 3 \\
5 & 5 & 4 & 3 & 4 & 3 & 5 & 5 & 5 & 3 & 4 & 3 & 4 & 3 & 3 & 4 \\
3 & 4 & 4 & 4 & 3 & 4 & 3 & 5 & 5 & 4 & 4 & 4 & 2 & 2 & 3 & 3 \\
3 & 2 & 4 & 2 & 3 & 2 & 5 & 5 & 3 & 2 & 3 & 2 & 3 & 2 & 3 & 3
\end{array}\right\}
$$


First, the normalization of $\mathrm{X}$ matrix as follows:

$$
\begin{array}{ll}
\mathrm{r}_{11}=\frac{5}{\max \{(5),(5),(5)(3)(3)\}}=\frac{5}{5}=1 & \mathrm{r}_{91}=\frac{3}{\max \{(3),(3),(5),(5),(3)\}}=\frac{3}{5}=0,6 \\
\mathrm{r}_{21}=\frac{4}{\max \{(4),(3),(5)(4)(2)\}}=\frac{4}{5}=0,8 & \mathrm{r}_{101}=\frac{5}{\max \{(5),(3),(3),(4),(2)\}}=\frac{5}{5}=1 \\
\mathrm{r}_{31}=\frac{3}{\max \{(3),(3),(4)(4)(4)\}}=\frac{3}{4}=0,75 & \mathrm{r}_{111}=\frac{3}{\max \{(3),(4),(4),(4),(3)\}}=\frac{3}{4}=0,75 \\
\mathrm{r}_{41}=\frac{4}{\max \{4,(3),(3)(4)(2)\}}=\frac{4}{4}=1 & \mathrm{r}_{121}=\frac{2}{\max \{(2),(3),(3),(4),(2)\}}=\frac{2}{4}=0,5 \\
\mathrm{r}_{51}=\frac{2}{\max \{(2),(2),(4)(3)(3)\}}=\frac{2}{4}=0,5 & \mathrm{r}_{131}=\frac{4}{\max \{(4),(2),(4),(2),(3)\}}=\frac{4}{4}=1 \\
\mathrm{r}_{61}=\frac{3}{\max \{(3),(3),(3),(4),(2)\}}=\frac{3}{4}=0,75 & \mathrm{r}_{141}=\frac{5}{\max \{(3),(3),(3),(2),(2)\}}=\frac{3}{3}=1 \\
\mathrm{r}_{71}=\frac{5}{\max \{(5),(5),(5),(3),(5)\}}=\frac{5}{5}=1 & \mathrm{r}_{151}=\frac{4}{\max \{(4),(3),(3),(3),(3)\}}=\frac{4}{4}=1 \\
\mathrm{r}_{81}=\frac{5}{\max \{(5),(5),(5),(5),(5)\}}=\frac{5}{5}=1 & \mathrm{r}_{161}=\frac{4}{\max \{(4),(3),(4),(3),(3)\}}=\frac{4}{4}=1
\end{array}
$$

The second makes normalization of matrix $\mathrm{R}$ obtained from result of normalization of $\mathrm{X}$ matrix as follows:

$$
\left\{\begin{array}{ccccccccccccccc}
1 & 0,8 & 0,75 & 1 & 0,5 & 0,75 & 1 & 1 & 0,6 & 1 & 0,75 & 0,5 & \ldots & 1 & 1 \\
1 & 0,6 & 0,75 & 0,75 & 0,5 & 0,75 & 1 & 1 & 0,6 & 0,6 & 1 & 0,75 & \ldots & 0,75 & 0,75 \\
1 & 1 & 1 & 0,75 & 1 & 0,75 & 1 & 1 & 1 & 0,6 & 1 & 0,75 & \ldots & 0,75 & 1 \\
0,6 & 0,8 & 1 & 1 & 0,75 & 1 & 0,6 & 1 & 1 & 0,8 & 1 & 1 & \ldots & 0,75 & 0,75 \\
0,6 & 0,4 & 1 & 0,5 & 0,75 & 0,5 & 1 & 1 & 0,6 & 0,4 & 0,75 & 0,5 & \ldots & 0,75 & 0,75
\end{array}\right\}
$$

Next, it will be made multiplication between $\mathrm{W} x \mathrm{R}$ and the sum of multiplication products to obtain the best alternative by doing the ranking process using the weight given by the decision maker. The results obtained are as follows, as shown in Table 4.

Table 4. Alternative results obtained

\begin{tabular}{cc}
\hline \multicolumn{2}{c}{ Alternative Values } \\
\hline $\mathrm{V}_{1}$ & 68,25 \\
$\mathrm{~V}_{2}$ & 61,50 \\
$\mathrm{~V}_{3}$ & 73,00 \\
$\mathrm{~V}_{4}$ & 66,08 \\
$\mathrm{~V}_{5}$ & 54,58 \\
\hline
\end{tabular}


Based on the appraisal performance of extensionist using Fuzzy Simple Additive Wighted method, the result is obtained as shown in Table 4. Then it can be seen that the biggest value is V3 so alternative A3 is the chosen alternative as the best alternative. Then, Extensionist Number three (Sudirman) as a counselor who has a Better Performance.

\subsection{Application of the Exponential Comparison Method (MPE)}

The implementation of exponential comparisons for the assessment of agricultural extension officers is taken for example 5 agricultural extension data with the criterion value, as shown in Table 4 and the quantitative value seen in Table 5.

Table 5. Weight value quantitative

\begin{tabular}{cl}
\hline Weight & \multicolumn{1}{c}{ Value } \\
\hline 1 & Less important weights \\
2 & Standar with weights \\
3 & Quite important weights \\
4 & Important with weights \\
5 & Very Important weights \\
\hline
\end{tabular}

Table 6.The alternate value

\begin{tabular}{lcccccccccc}
\hline \multirow{2}{*}{ Alternative } & \multicolumn{10}{c}{ Criteria } \\
\cline { 2 - 11 } & $\mathrm{C}_{1}$ & $\mathrm{C}_{2}$ & $\mathrm{C}_{3}$ & $\mathrm{C}_{4}$ & $\mathrm{C}_{5}$ & $\mathrm{C}_{6}$ & $\mathrm{C}_{7}$ & $\mathrm{C}_{8}$ & $\mathrm{C}_{9}$ & $\mathrm{C}_{10}$ \\
\hline Sirajudin & 5 & 4 & 3 & 4 & 2 & 3 & 5 & 5 & 3 & 5 \\
Nasir Lubis & 5 & 3 & 3 & 3 & 2 & 3 & 5 & 5 & 3 & 3 \\
Sudirman & 5 & 5 & 4 & 3 & 4 & 3 & 5 & 5 & 5 & 3 \\
Sugianto & 3 & 4 & 4 & 4 & 3 & 4 & 3 & 5 & 5 & 4 \\
Eko Susanto & 3 & 2 & 4 & 2 & 3 & 2 & 5 & 5 & 3 & 2 \\
\hline
\end{tabular}

Table 6 . The alternate value

\begin{tabular}{lcccccc}
\hline \multirow{2}{*}{ Alternative } & \multicolumn{6}{c}{ Criteria } \\
\cline { 2 - 7 } & $\mathrm{C}_{11}$ & $\mathrm{C}_{12}$ & $\mathrm{C}_{13}$ & $\mathrm{C}_{14}$ & $\mathrm{C}_{15}$ & $\mathrm{C}_{16}$ \\
\hline Sirajudin & 3 & 2 & 4 & 3 & 4 & 4 \\
Nasir Lubis & 4 & 3 & 2 & 3 & 3 & 3 \\
Sudirman & 4 & 3 & 4 & 3 & 3 & 4 \\
Sugianto & 4 & 4 & 2 & 2 & 3 & 3 \\
Eko Susanto & 3 & 2 & 3 & 2 & 3 & 3 \\
\hline
\end{tabular}


The weight of for each criterion shown in Table 7.

Table 7. Weights important

\begin{tabular}{cccc}
\hline Criterion Code & Criteria & $\begin{array}{c}\text { Criterion } \\
\text { Code }\end{array}$ & Criteria \\
\hline $\mathrm{C}_{\mathrm{I}}$ & 5 & $\mathrm{C}_{9}$ & 5 \\
$\mathrm{C}_{2}$ & 5 & $\mathrm{C}_{10}$ & 5 \\
$\mathrm{C}_{3}$ & 5 & $\mathrm{C}_{11}$ & 5 \\
$\mathrm{C}_{4}$ & 5 & $\mathrm{C}_{12}$ & 5 \\
$\mathrm{C}_{5}$ & 5 & $\mathrm{C}_{13}$ & 5 \\
$\mathrm{C}_{6}$ & 5 & $\mathrm{C}_{14}$ & 5 \\
$\mathrm{C}_{7}$ & 5 & $\mathrm{C}_{15}$ & 5 \\
$\mathrm{C}_{8}$ & 5 & $\mathrm{C}_{16}$ & 5 \\
\hline
\end{tabular}

He next step is to assess all alternatives on each criterion by using the MPE formula.

Sirajudin $=5^{\wedge} 5+4^{\wedge} 5+3^{\wedge} 5+4^{\wedge} 5+2^{\wedge} 5+3^{\wedge} 5+5^{\wedge} 5+5^{\wedge} 5+3^{\wedge} 5$

$+5^{\wedge} 5+3^{\wedge} 5+2^{\wedge} 5+4^{\wedge} 5+3^{\wedge} 5+4^{\wedge} 5+4^{\wedge} 5$

Nasir Lubis $=5^{\wedge} 5+3^{\wedge} 5+3^{\wedge} 5+3^{\wedge} 5+2^{\wedge} 5+3^{\wedge} 5+5^{\wedge} 5+5^{\wedge} 5+3^{\wedge} 5+$ $3^{\wedge} 5+4^{\wedge} 5+3^{\wedge} 5+2^{\wedge} 5+3^{\wedge} 5+3^{\wedge} 5+3^{\wedge} 5$

Sudirman $=5^{\wedge} 5+5^{\wedge} 5+4^{\wedge} 5+3^{\wedge} 5+4^{\wedge} 5+3^{\wedge} 5+5^{\wedge} 5+5^{\wedge} 5+5^{\wedge} 5+$ $3^{\wedge} 5+4^{\wedge} 5+3^{\wedge} 5+4^{\wedge} 5+3^{\wedge} 5+3^{\wedge} 5+4^{\wedge} 5$

Sugianto $=3^{\wedge} 5+4^{\wedge} 5+4^{\wedge} 5+4^{\wedge} 5+3^{\wedge} 5+4^{\wedge} 5+3^{\wedge} 5+6^{\wedge} 5+6^{\wedge} 5+$ $4^{\wedge} 5+4^{\wedge} 5+4^{\wedge} 5+2^{\wedge} 5+2^{\wedge} 5+3^{\wedge} 5+3^{\wedge} 5$

Eko Susanto $=3^{\wedge} 5+2^{\wedge} 5+4^{\wedge} 5+2^{\wedge} 5+3^{\wedge} 5+2^{\wedge} 5+5^{\wedge} 5+5^{\wedge} 5+3^{\wedge} 5+$ $2^{\wedge} 5+3^{\wedge} 5+2^{\wedge} 5+3^{\wedge} 5+2^{\wedge} 5+3^{\wedge} 5+3^{\wedge} 5$

Calculate the score or total value of each alternative, the results can be seen in Table 8.

Table 8. MPE score calculation results for each alternative

\begin{tabular}{lcccccc}
\hline \multirow{2}{*}{ Alternative } & \multicolumn{5}{c}{ Criteria } & NP \\
\cline { 2 - 6 } & $\mathrm{C}_{1}$ & $\mathrm{C}_{2}$ & $\mathrm{C}_{\mathrm{n}}$ & $\mathrm{C}_{15}$ & $\mathrm{C}_{16}$ & \\
\hline Sirajudin & 3125 & 1024 & $\ldots$ & 1024 & 1024 & 18899 \\
$\begin{array}{l}\text { Nasir } \\
\text { Lubis }\end{array}$ & 3125 & 243 & $\ldots$ & 243 & 243 & 12893 \\
Sudirman & 3125 & 3125 & $\ldots$ & 243 & 1024 & 22203 \\
$\begin{array}{l}\text { Sugianto } \\
\text { Eko }\end{array}$ & 243 & 1024 & $\ldots$ & 243 & 243 & 14697 \\
Susanto & 243 & 32 & $\ldots$ & 243 & 243 & 9167 \\
\hline
\end{tabular}

After the MPE score calculation results are obtained for each alternative then determine the priority of the decision based on the total value of each alternative 
based on the highest value, which can be seen in Table 9

Table 9. Rating results

\begin{tabular}{lcc}
\hline \multicolumn{1}{c}{ Subject } & Decision Value MPE & Rank \\
\hline Sudirman & 22203 & 1 \\
Sirajudin & 18899 & 2 \\
Sugianto & 14697 & 3 \\
Nasir Lubis & 12893 & 4 \\
Eko Susanto & 9167 & 5 \\
\hline
\end{tabular}

Based on the appraisal of extension performance using Exponential Comparison method, the result is obtained as in Table 9. Then it can be seen the greatest value is named Sudirman as a counselor who has better performance.

\section{CONCLUSION}

The results of the analysis of Simple Additive Wighted and Exponential Comparison methods in the appraisal of agricultural extension performance at UPT BPP Sukaraja give the result that the two applied methods get the final calculation of agricultural extension performance with the same rank. By calculating the same criteria value using two methods, it resulted in a ranking of extension performance with the same decision result.

\section{REFERENCES}

[1] Sapar, S., \& Butami, L. (2017). Faktor-Faktor yang Mempengaruhi Kinerja Penyuluh Pertanian dalam Peningkatan Produktivitas Kakao di Kota Palopo. Jurnal Ekonomi Pembangunan, 3(1), 35-42.

[2] Manik. (2015). Sistem Pendukung Keputusan Menentukan Tenaga Pengajar pada Sekolah Luar Biasa (SLB) dengan Menggunakan Metode Simple Addtive Weighting (SAW). Medan: Pelita Informatika Budi Darma.

[3] Sari, F. (2018). Metode dalam Pengambilan Keputusan. Deepublish.

[4] Maulana, M. R. (2012). Penilaian Kinerja Karyawan di Ifun Jaya Textile dengan metode Fuzzy Simple Additive Weighted. Jurnal Ilmiah ICTech, 10(1), 12.

[5] Kusumadewi, S. (2006). Fuzzy Multi-Attribute Decision Making. Yogyakarta: Graha Ilmu.

[6] Kusumadewi, S., Hartati, S. (2006). Fuzzy Multi Attribute Decision Making Fuzzy-MADM. Yogyakarta: Penerbit Andi.

[7] Marimin, M. (2004). Teknik dan Aplikasi Pengambilan Keputusan Kriteria Majemuk. Jakarta: PT. Grasindo. 